\title{
GENERAL INFLUENCE OF BIPHASIC CALCIUM PHOSPHATE ON OSTEOPOROTIC BONE DENSITY
}

\author{
Vladislavs Ananjevs ${ }^{1, \#}$, Alekșandra Ananjeva ${ }^{2}$, Jānis Vētra ${ }^{3}$, Andrejs Skaǵers ${ }^{1}$, \\ Ilze Salma ${ }^{1}$, Laura Neimane ${ }^{1}$, and Vladimir Kasyanov ${ }^{4}$ \\ ${ }^{1}$ Department of Oral and Maxillofacial Surgery, Rīga Stradinš University, 20 Dzirciema Str., Rīga, LV-1007, LATVIA \\ ${ }^{2}$ Faculty of Continuing Education, Study Programme Residency in Medicine, Rīga Stradinš University, \\ 16 Dzirciema Str., Rīga, LV-1007, LATVIA \\ ${ }^{3}$ Institute of Anatomy and Anthropology, Rīga Stradinš University, Eksporta Str., Rīga, LV-1010, LATVIA \\ ${ }^{4}$ Laboratory of Biomechanics, Rīga Stradiṇš University, 5 Rātsupītes Str., Rīga, LV-1067, LATVIA \\ \# Corresponding author, v.ananjevs@gmail.com
}

Contributed by Vladimir Kasyanov

\begin{abstract}
Bone density of the femur body of rabbit was determined in vivo. Experimental osteoporosis was induced by ovariectomy and subsequent injections of methylprednisolone. In the greater trochanter region of right femur, defects were created and filled with granules of hydroxyapatite and tricalcium phosphate (HAP/TCP 70/30) or HAP/TCP 70/30 together with 5\% strontium. After three months, the animals were euthanized. The bone mass density of the right and left body of femur was measured by cone beam computed tomography (CT) scan. The results of the study showed that the right femur of the rabbit, where biomaterials had been implanted, and the left femur, where no biomaterial implantation occurred, became denser after filling the defect with HAP/TCP $70 / 30$ ceramic granules or $5 \% \mathrm{Sr}$ modified HAP/TCP ceramic granules. There was no difference between operated and non-operated legs and HAP/TCP and HAP/TCP with 5\% strontium groups.
\end{abstract}

Key words: bone density, osteoporosis, biphasic calcium phosphate, in vivo, strontium.

Bone regeneration is the physiological process of bone formation that occurs during normal fracture healing, and is involved in continuous remodelling throughout adult life. However, there are complex clinical conditions in which extensive bone regeneration is needed, for example, in cases of osteoporosis (Dimitriou et al., 2011).

Bone grafting is one of the most commonly used surgical methods to augment bone in orthopaedic procedures. Bioceramic materials have enormous potential for natural bone tissue repair (Wang et al., 2017). Calcium phosphates bone grafts are among the best-known and clinically established means of bone repair. This material provides bone with the following characteristics: osteoconductivity, biocompatibility and biodegradation (Carsten et al., 2015). Biphasic calcium phosphate ceramic as a bone replacement material is used to improve the properties of osteoporotic bones and promote bone tissue healing. Calcium hydroxyapatite is highly bioaccumulative and forms a direct bond with bone tissue. Tricalcium phosphate acts as a catalyst for stimulating the formation of new bone tissue (Ratner et al., 2013). Strontium-releasing calcium phosphate bone cements are prospective materials for the clinical regeneration of osteoporosis-related bone defects, because they stimulates bone formation and at the same time limit osteoclastic bone resorption (Lode et al., 2017).

Previous studies have investigated the effect of biomaterials on bone regeneration in the site of implantation. The aim of the present study was to determine how local addition of biphasic calcium phosphate materials in the femur trochanter area affects bones mineral density outside the implantation zone in vivo. We examined rabbit femur after ovariectomy and subsequent implantation of calcium hydroxyapatite with tricalcium phosphate in proportion 70/30, without or with 5\% strontium; in comparison to nonoperated and sham surgery legs as controls. 
Experimental osteoporosis was induced in 19 eight-month old female rabbits after ovariectomy followed by $1 \mathrm{mg} / \mathrm{kg}$ daily methylprednisolone injection. The duration of the treatment was six weeks. Defects were created in the right femur greater trochanter region in 15 rabbits. Femur of seven animals were filled with biphasic ceramics (HAP/TCP 70/30), and the remaining eight were filled with $5 \% \mathrm{Sr}$ modified biphasic ceramics. The sham surgery group consisted of four female rabbits with similar bone defects, but without implantation of biomaterials. After three months, the animals were euthanized (Fig. 1). Permission of the study was received by the Animal Ethics Committee of Food and Veterinary Administration of Latvia.

The bone mass density of the right (operated) and left (non-operated) femur body was measured by cone beam CT scan using iCAT Next Generation (KAVO, Germany) in Rīga Stradiņš University, Institute of Stomatology, Department of Oral and Maxillofacial Diagnostic Radiology. The hardware was used with a standard operating protocol (voltage $120 \mathrm{KV}$, current strength $38 \mathrm{~mA}$, test field (FOV) 17 $\mathrm{cm}$, resolution 0.4 units).

The obtained test data were processed and analysed using hardware-specific software iCAT eXamVision (Kavo, Germany). The voxel value of suppression of the image in the femur body was determined. The values, which were displayed in Hawsfield units (HU), were converted to $1: 1$ values of radiological suppression in units (Do-Gyoon Kim,
2014). Determination of the image blackout value was done in a $4 \mathrm{~mm}^{2}$ field (Fig. 2).

Statistical data analysis, calculation and all graphs were made using software GraphPad PRISM version 6.0e (GraphPad Software Inc., San Diego, California, USA). Unequal SD comparison of medians between different groups was performed with the Mann-Whitney test. All biomechanical parameters were presented as medians (Md) with interquartile range (IQR). Two values were considered as statistically significantly different if the $p$-value was less than $0.05(p<0.05)$.

The test samples were divided into three treatment groups: sham surgery treatment (group A), HAP/TCP treatment (group B) and HAP/TCP with 5\% Sr treatment (group C). The results of the study showed that in the sham surgery group, bone density in the right (operated) and the left (non-operated) body of the femur was less than in the other two groups.

The bone density in the operated body of the femur in group A was $923 \mathrm{HU}$ (range 1056-843.5), which was statistically significantly lower $(p=0.016)$ than in group B $(1302 \mathrm{HU}$, range 1350-1209) and C group (1344 HU, range 1459$1156), p=0.042$. Statistically significant differences between groups B and C were not found ( $p=0.761$ ) (Fig. 3).

The density of non-operated body of the femur bone in group A was 935.5 HU (range 1053-876), which was sig-

19 rabbits with experimental osteporosis

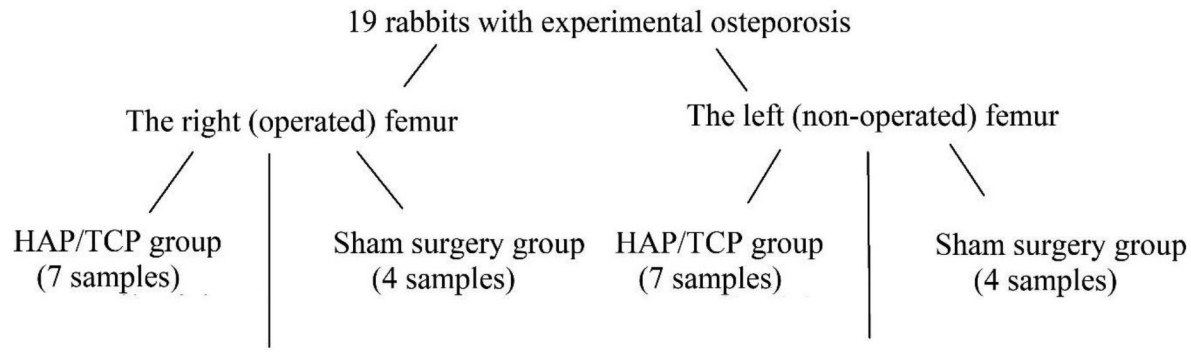

HAP/TCP with $5 \% \mathrm{Sr}$ group (8 samples)

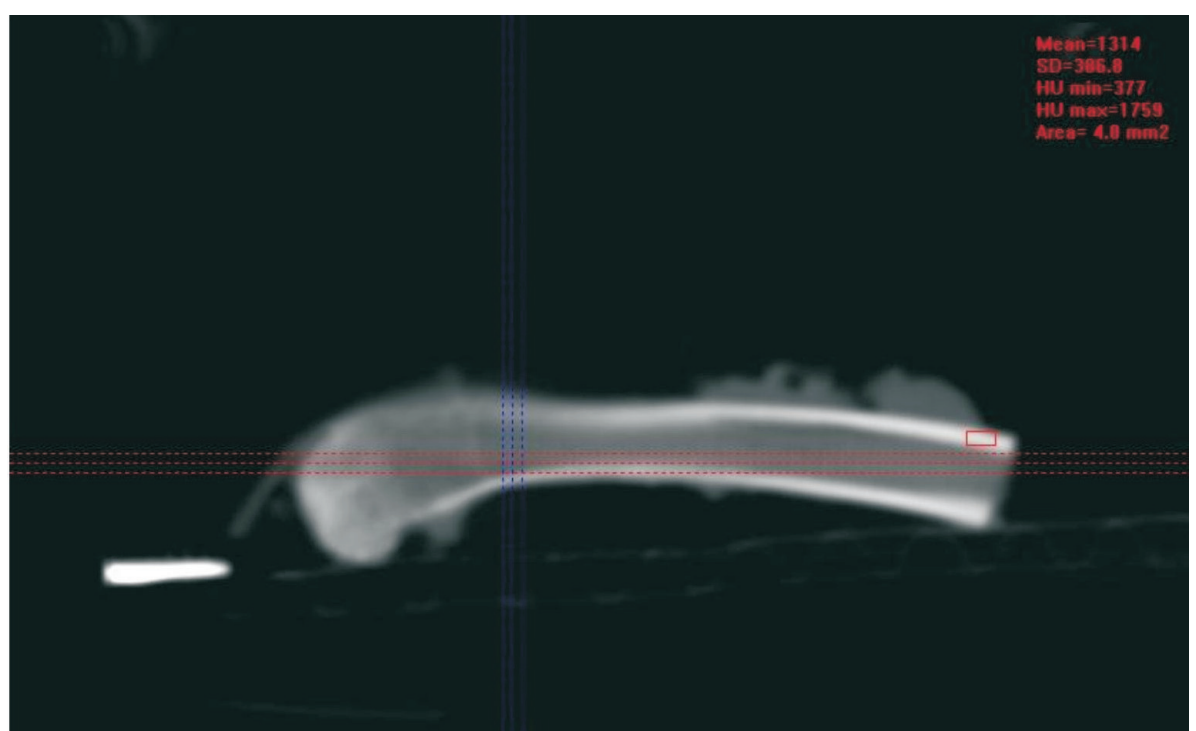

Fig. 1. A scheme of the rabbit treatment groups.
Fig. 2. Cone beam CT scan image for determination of suppression level ion the femur body - sagittal plane view. Red lines - coronal plane view, blue lines - axial plane view. 


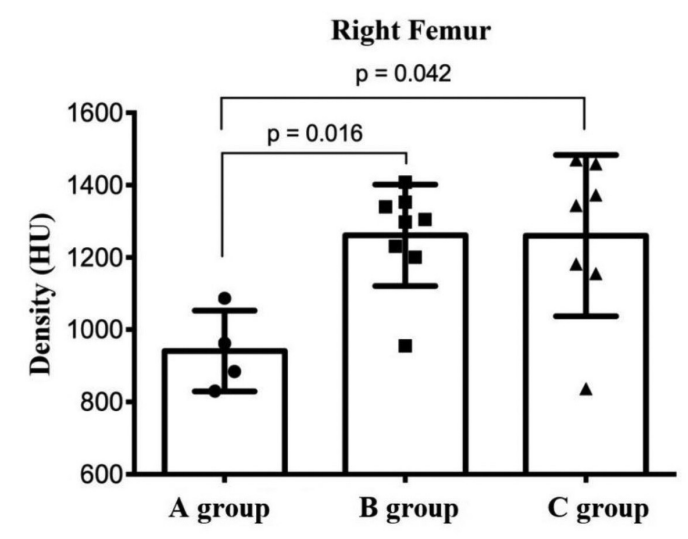

Fig. 3. Bone density values of the right body of the femur.

nificantly less $(p=0.016)$ than in group B (1212 HU, range 1360-1138) and in C group (1261 HU, range 1315-1090), $p=0.012$. Statistically significant differences between groups B and C were not found ( $p=0.99)$. (Fig. 4).

Biphasic calcium phosphate (BCP) ceramic can be used as bone grafting material to strengthen osteoporotic bone and to improve bone healing. BCP materials have high bioactivity. It is supposed that TCP, which has a minor amount of in the composition, has a relatively faster resorption rate compared to HAP and will ensure the initial burst of release of calcium and orthophosphate ions into the blood vessels, thus seeding new bone formation (Salma et al., 2015). In our study there were no statistically significant differences in bone density between operated and non-operated legs.

The major calcium phosphate biomaterials are not homogenous and contain trace elements that have been found to play a vital function in growth and bone repair (Ehret et al., 2017). In vitro and in vivo studies have indicated that strontium increases bone formation and reduces bone resorption (Landi et al., 2007). The dual effects of strontium to increase bone formation and inhibit bone resorption have been widely reported. Strontium doped in calcium phosphate still showed a positive effect on osteoblasts and had an inhibitory effect on osteoclasts in in vitro experiments. (Li et al., 2015). Since strontium acts as a dual agent, the optimal amount of strontium remains a subject of investigation. As described in the literature, the levels of strontium in bioceramics vary from $1 \%$ to $100 \%$ (Ehret et al., 2017). At low concentrations, strontium administration was shown to reduce bone resorption and stimulate bone formation (Jegou Saint-Jean et al., 2005). In our study biphasic ceramic granules enriched with $5 \%$ strontium showed the same results than HAP/TCP alone.

The study found that the right femur of the rabbit, where the biomaterial is implanted, became denser after filling the defects with HAP/TCP $70 / 30$ ceramic granules or $5 \% \mathrm{Sr}$ modified HAP/TCP ceramic granules, compared to the left femur in which no biomaterial implantation was performed. There were no significant differences in bone density between operated and non-operated legs. There were also no significant differences between treatments with HAP/TCP

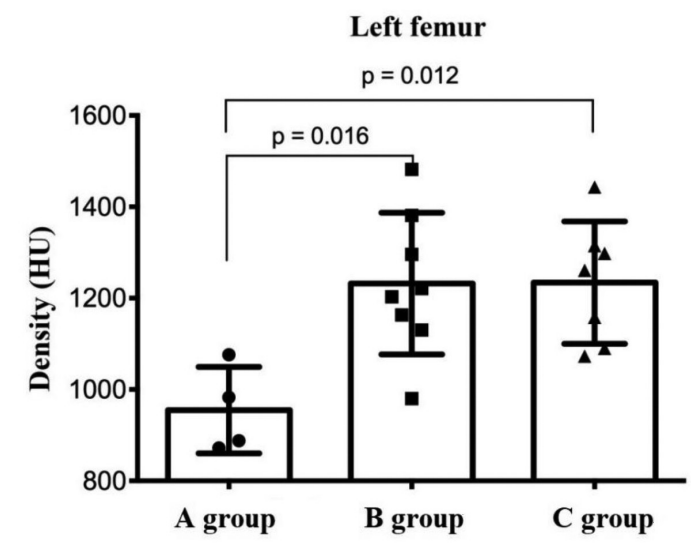

Fig. 4. Bone density values of the left body of the femur

and HAP/TCP with 5\% strontium groups. It might be possible to achieve better results with strontium in greater concentration. Further studies are needed with different amounts of strontium in order to better understand its role in bone repair mechanisms.

\section{ACKNOWLEDGMENTS}

The study was supported by the National Research Programme No. 2014.10-4/VPP-3/21 "Multifunctional Components and composites, photonics and nanotechnology". Project No. 4 "Nanocomponents and nanotechnologies for medical applications".

\section{REFERENCES}

Dimitriou, R., Jones, E., McGonagle, D., Giannoudis, P. V. (2011). Bone regeneration: Current concepts and future directions. BMC Med., 9, 66-71.

Ehret, C., Aid-Launais, R., Sagardoy, T., Siadous, R., Bareille, R., Rey, S., Pechev, S., Etienne, L., Kalisky, J., de Mones, E., Letourneur, D., Amedee Vilamitjana, J. (2017). Strontium-doped hydroxyapatite polysaccharide materials effect on ectopic bone formation. PLoS One, 12 (9), e0184663.

Kim, D. G. (2014). Can dental cone beam computed tomography assess bone mineral density? J. Bone Metab., 21 (2), 117-126.

Landi, E., Tampieri, A., Celotti, G., Sprio, S., Sandri, M., Logroscino, G. (2007). Sr-substituted hydroxyapatites for osteoporotic bone replacement, Acta Biomater., 3 (6), 961-969.

Li, Y., Luo, E., Zhu, S., Li, J., Zhang, L., Hu, J. (2015). Cancellous bone response to strontium-doped hydroxyapatite in osteoporotic rats. J. Appl. Biomater. Funct. Mater., 13 (1), 28-34.

Lode, A., Heiss, C., Knapp, G., Thomas, J., Nies, B., Gelinsky, M., Schumacher, M. (2017). Strontium-modified premixed calcium phosphate cements for the therapy of osteoporotic bone defects. Acta Biomater., 1, 30664-30665.

Ratner, B. D., Hoffman, A. S., Schoen, F. J., Lemons, J. E. (2013). Biomaterials Science: An Introduction to Materials in Medicine. $3^{\text {rd }}$ edn. Elsevier. 1573 pp.

Saint-Jean, S. J., Camire, C. L., Nevsten, P., Hansen, S., Ginebra, M. P. (2005). Study of the reactivity and in vitro bioactivity of Sr-substituted $\alpha$-TCP cement. J. Mater. Sci. Mater. Med., 16, 993-1001.

Salma, I., Petronis, S., Pilmane, M., Skagers, A., Zalite, V., Locs, J. (2015). Local recovery of bone tissue in osteoporotic rabbit hip after implantation of HAP/TCP bioceramic granules. In: $27^{\text {th }}$ European Conference on Biomaterials: Final Programme and Book of Abstracts, Krakov, Poland, 
$30^{\text {th }}$ August $-3^{\text {rd }}$ September, 2015. Scientific Publishing House "Akapit", Krakow, p. 409. Available at: http://www.proceedings.com/28321.html (accessed 18.02.2019).

Schlickewei, C. W., Laaff, G., Andresen, A., Klatte, T. O., Rueger, J. M., Ruesing, J., Epple, M., Lehmann, W. (2015). Bone augmentation using a new injectable bone graft substitute by combining calcium phosphate and bisphosphonate as composite: An animal model. J. Orthop. Surg. Res., 10, 116.

Wang, W., Yeung, K. W. K. (2017). Bone grafts and biomaterials substitutes for bone defect repair: A review. Bioact. Mater., 2, 224-247.

Received 7 November 2018

Accepted in the final form 19 February 2019

\section{BIFĀZISKA KALCIJA FOSTĀTA VISPĀRĒJĀ IETEKME UZ OSTEOPOROTISKU KAULU MINERĀLBLĪVUMU}

Tika veikta labās un kreisās kājas augšstilba ḳermeṇa dạas kaula blīvuma mērī̌sana trušiem ar eksperimentālo osteoporozi, izmantojot konisku stara datortomogrāfiju palīdzību (iCAT Next Generation, KAVO, Vācija). Iegūtie izmeklējumu dati tika apstrādāti un analizēti, izmantojot aparatūrai atbilstošo programmatūru iCAT eXamVision (Kavo, Vācija). Eksperimentālā osteoporoze tika izraisīta astoṇus mēnešus veciem sievišķā dzimuma trušiem pēc ovarektomijas un tai sekojošas $1 \mathrm{mg} / \mathrm{kg}$ dienā metilprednozolona injekcijas. Terapijas ilgums bija sešas nedēlas. Trušiem tika izveidoti defekti labās kājas augšstilba trochanter majus rajonā. Defekti tika aizpildīti ar bifāzisku keramiku (HAP/TCP 70/30) vai 5\% Sr modificētu divfāžu keramiku. Placebo ķirurğijas grupai tika izveidots identisks kaula defekts, bet netika implantēta biokeramika. Pēc trim mēnešiem dzīvniekiem tika veikta eitanāzija. Pētījumā tika konstatēts, ka trušu labās kājas augšstilba kauls, kur tika veikta biomateriāla implantācija, un kreisās kājas augšstilba kauls, kur netika veikta biomateriāla implantācija, kḷuva blīvāks pēc defekta aizpildīšanas ar HAP/TCP 70/30 keramikas granulām vai ar 5\% Sr modificētas HAP/TCP keramikas granulām. Statistiski ticamas atšķirības starp HAP/TCP un ar 5\% Sr modificētu divfāžu keramiku grupām, operētu un neoperētu augšstilbu netika atrastas. 